\title{
PENERAPAN MODEL PEMBELAJARAN KOOPERATIF TIPE STAD DENGAN MEDIA SOFTWARE PESONA EDU UNTUK MENINGKATKAN PRESTASI BELAJAR MATEMATIKA SISWA
}

\author{
Ai Juhaeroh \\ SMP Negeri 7, Jl. Letnan Dadi Suryatman No.76, Kec.Cipedes, Kota Tasikmalaya, Indonesia \\ Email: info_smpn8tsm@yahoo.co.id
}

\begin{abstract}
This research is based on initial observations showing the results of mathematics learning students grade IX-A SMP Negeri 7 Tasikmalaya more than $50 \%$ have not reached $\mathrm{kkm}$ and the implementation of learning is still centered on teachers, resulting in students becoming passive. Therefore, efforts are needed to overcome the problem. This study aims to describe the improvement of mathematics learning outcomes and student activities through the application of cooperative learning models of Student Team Achievement Divisions (STAD) with Pesona Edu software media. This research is PTK (Class Action Research) conducted in two cycles. Each cycle includes four stages, namely action planning, action execution, evaluation, and reflection. This research instrument is an observation sheet to assess student activities and tests to assess the results of mathematics learning. The data that has been collected is then analyzed using descriptive methods. Based on the analysis of research data obtained student learning outcomes increased from a classical completion score of $25 \%$ and an average of 62 in cycle I to classical completion of $87,5 \%$ and an average learning outcome of 78,22 in cycle II. Besides, based on the observations there is an increase in students' learning activities during the learning process. This means that mathematics learning with cooperative model type STAD utilizing Pesona Edu media software can improve the results of mathematics learning and student activities so that this learning model can be an alternative in mathematics learning.
\end{abstract}

Keywords: Cooperative STAD, learning achievements, pesona edu

\begin{abstract}
ABSTRAK
Penelitian ini dilatarbelakangi dari observasi awal menunjukkan hasil belajar matematika siswa kelas IX A SMP Negeri 7 Tasikmalaya lebih dari $50 \%$ belum mencapai KKM dan pelaksanaan pembelajarannya masih berpusat kepada guru, sehingga mengakibatkan siswa menjadi pasif. Oleh karena tu, diperlukan upaya mengatasi persoalan tersebut. Penelitian ini bertujuan untuk mendeskripsikan peningkatan hasil belajar matematika dan aktivitas siswa melalui penerapan model pembelajaran kooperatif tipe Student Team Achievement Divisions (STAD) dengan media software Pesona Edu. Penelitian ini adalah PTK (Penelitian Tindakan Kelas) yang dilaksanakan dalam dua siklus. Masing-masing siklusnya meliputi empat tahap yaitu perencanaan tindakan, pelaksanaan tindakan, evaluasi, serta refleksi. Instrumen penelitian ini berupa lembar observasi guna menilai aktivitas siswa dan tes untuk menilai hasil belajar matematika. Data yang sudah dikumpulkan kemudian dilakukan analisis menggunakan metode deskriptif. Berdasarkan analisis data penelitian diperoleh hasil belajar siswa meningkat dari nilai ketuntasan klasikal $25 \%$ dan rata-rata 62 pada siklus I menjadi ketuntasan klasikal sebesar $87,5 \%$ dan rata-rata hasil belajar 78,22 pada siklus II. Selain itu berdasarkan hasil observasi terdapat peningkatan aktivitas belajar siswa selama dilakukannya proses pembelajaran. Artinya pembelajaran matematika dengan model kooperatif tipe STAD memanfaatkan media software Pesona Edu dapat meningkatkan hasil belajar matematika dan aktivitas siswa, sehingga model pembelajaran ini dapat menjadi alternatif dalam pembelajaran matematika.
\end{abstract}

Kata kunci: Kooperatif STAD, pesona edu, prestasi belajar

Dikirim: 1 Februari 2021; Diterima: 13 Februari 2021; Dipublikasikan: 30 Maret 2021

Cara sitasi: Juhaeroh, A. (2021). Penerapan model pembelajaran kooperatif tipe stad dengan media software pesona edu untuk meningkatkan prestasi belajar matematika siswa. Teorema: Teori dan Riset Matematika, 6 (1), 107-116. Doi: http://dx.doi.org/10.25157/teorema.v6i1.4982 


\section{PENDAHULUAN}

Hingga kini matematika masih dianggap sebagai mata pelajaran yang menakutkan, membosankan, dan sulit. Asumsi tersebut bukanlah sesuatu yang berlebihan karena beberapa konsep yang dipelajari dalam matematika merupakan hal yang kurang kontekstual sehingga siswa kesulitan memahaminya. Padahal sebenarnya pembelajaran matematika tidak dapat dipisahkan dari konteks kehidupan sehari-hari karena sejatinya matematika adalah manifestasi ide-ide dari dunia nyata (Munaji \& Setiawahyu, 2020). Selain itu guna mempelajari konsep baru dalam matematika dibutuhkan syarat-syarat memahami konsep sebelumnya. Mata pelajaran matematika akan mampu membentuk pola pikir seseorang untuk berpikir terstuktur dan logis, sehingga matematika perlu dipelajari sedini mungkin (Aprilia \& Putri, 2020). Matematika termasuk sarana berpikir ilmiah dimana dibutuhkan untuk menunjang peningkatan kemampuan berpikir kritis, sistematis, serta logis bagi peserta didik (Rakhmawati, 2012). Konsep dalam matematika banyak yang berupa konsep abstrak, oleh karena itu guru harus menentukan media serta model pembelajaran yang akan disampaikannya agar tujuan pembelajaran bisa tercapai.

Agar tujuan pembelajaran dapat tercapai, guru harus mampu mengorganisir seluruh komponen sehingga antar komponen bisa berinteraksi dengan harmonis. Komponen dalam pembelajaran diantaranya ialah memanfaatkan bermacam metode dan strategi pembelajaran secara fleksibel dan dinamis sesuai dengan konteks pembelajaran, siswa, dan materi (Suhito, 2000). Dengan demikian guru dituntut untuk mampu menentukan media serta model pembelajaran yang selaras dengan bahan ajar atau materi.

Menurut Sobel \& Maletsky (2001) tidak sedikit guru matematika yang memanfaatkan waktu pelajaran untuk membahas tugas, kemudian memberikan pelajaran baru, dan juga siswa diberikan tugas kembali. Kegiatan belajar mengajar semacam ini yang pelaksanaannya hampir rutin setiap hari bisa dikelompokkan dalam 3M, yakni membosankan, membahayakan serta merusak seluruh minat peserta didik. Jika pembelajaran semacam ini dilakukan dengan terus-menerus maka indikator dan kompetensi dasar pembelajaran tidak akan bisa terwujud dengan optimal. Bukan hanya hal tersebut, memilih media yang tepat juga berperan krusial dalam pembelajaran.

Mengacu pada hasil observasi di kelas IX SMP Negeri 7 Kota Tasikmalaya hingga kini masih cukup banyak siswa yang mengalami beberapa kesulitan dalam mempelajari matematika. Kesulitan tersebut diantaranya ialah dalam memahami konsep pokok bahasan statistika dan peluang. Hasil belajar kognitif siswa lebih dari $50 \%$ belum mencapai standar Kriteria Ketuntasan Minimum (KKM) yang ada. Pelaksanaan proses pembelajaran matematika masih teacher centered (terpusat kepada guru). Oleh karenanya aktivitas siswa dalam proses belajar mengajar masih kurang. Siswa lebih cenderung pasif karena kurang mendapatkan stimulus yang bisa meningkatkan minat dan motivasinya terhadap pembelajaran matematika. Beberapa soal latihan yang diberikan kurang kontekstual, sehingga siswa cenderung hanya menghapal rumus tanpa mampu menganalisis lebih lanjut tentang pemecahan masalah yang diberikan. Hal ini mengakibatkan prestasi belajar siswa pada pembelajaran matematika rendah. Berdasarkan pemaparan tersebut, kiranya diperlukan pengembangan tindakan yang bisa menjadikan prestasi belajar matematika siswa meningkat.

Sebuah cara yang bisa guru lakukan dalam pembelajaran matematika ialah dengan memanfaatkan model pembelajaran kooperatif tipe Student Team Achievement Divisions (STAD). Melalui model ini dapat terjadi proses saling membantu antar anggota kelompok guna memecahkan masalah matematika dan memahami konsep-konsep matematika dengan kelompoknya (Mariani, 2016; Putri \& Sutriyono, 2018). Bukan hanya itu, pemakaian media dalam pembelajaran matematika juga akan sangat mendukung, sebab siswa akan lebih mudah dalam memahami konsep matematika yang abstrak dengan adanya media pembelajaran.

Media pembelajaran yang dimanfaatkan selama ini berupa alat peraga yang bahannya dibuat dari tripleks. Namun, perkembangan teknologi yang semakin pesat menjadikan media pembelajaran ini kurang menarik minat serta perhatian siswa. Sehingga, dibutuhkan sebuah media pembelajaran yang bisa menarik minat serta perhatian siswa dengan tidak mengurangi fungsi media 
pembelajarannya secara umum. Bisa disebutkan, guru dalam pembelajaran matematika dituntut untuk dapat menciptakan kondisi menyenangkan melalui alternatif media pembelajaran atau alat peraga yang dapat dipakai untuk beragam kondisi dan tempat, baik itu di rumah ataupun sekolah.

Salah satu media pembelajaran yang dapat digunakan adalah software dalam komputer. Software pembelajaran ialah program komputer yang secara khusus dirancang guna membantu dalam memahami suatu ilmu dan pengetahuan. Pemanfaatan software pembelajaran sebagai media akan membuat konsep matematika yang rumit menjadi lebih sederhana (Nurhayati et al., 2020). Dengan kata lain, konten yang dimanfaatkan sebagai sarana untuk mendampingi siswa belajar, atau alat bantu orangtua dan guru dalam mengajar. Salah satu software yang bisa dimanfaatkan dalam pembelajaran matematika ialah Pesona Edu. Pesona Edu menyediakan pembelajaran berbagai konsep matematika yang apabila disampaikan dengan cara konvensional umumnya susah dijelaskan. Melalui konten Pesona Edu pembelajaran konsep belajar disajikan berbentuk simulasi interaktif dan animasi yang kontekstual, jelas, dan indah, sehingga sangat mudah dipahami dan menarik minat siswa (Sastrawan et al, 2014).

Beberapa hasil penelitian memperlihatkan, multimedia interaktif berpengaruh terhadap prestasi belajar matematika dan kemampuan pemahaman konsep matematis siswa (Novitasari, 2016; Shodiqin \& Fakhrudin, 2011; Jamuri et al., 2015). Pemanfaatan media pembelajaran matematika dengan media software Pesona Edu memungkinkan untuk dipakai dalam beragam kondisi serta tempat, baik di rumah ataupun sekolah, dan yang paling utama yakni bisa memenuhi fungsi atau nilai dari media pembelajaran secara umum. Pengaplikasikan pembelajaran kooperatif tipe STAD memanfaatkan bantuan multimedia software berisi tayangan-tayangan yang menarik dapat memberikan peluang bagi siswa dalam memahami dan mencari penyelesaian permasalahan terkait pokok bahasan statistika dan peluang dalam kelompoknya masing-masing. Oleh karenanya bisa menjadikan hasil dan aktivitas belajar matematika siswa meningkat.

Berdasarkan latar belakang tersebut, dapat diuraikan tujuan penelitian ini ialah untuk mendeskripsikan peningkatan hasil belajar matematika dan aktivitas siswa kelas IX A SMP Negeri 7 Kota Tasikmalaya melalui penerapan model pembelajaran kooperatif tipe STAD dengan media software Pesona Edu.

\section{METODE PENELITIAN}

Penelitian ini dilakukan di kelas IX A SMP Negeri 7 Kota Tasikmalaya Tahun Pelajaran 2015/2016. Pelaksanaan penelitian ini pada bulan Oktober hingga awal bulan Desember 2015. Subyek penelitiannya yakni semua siswa kelas IX A sejumlah 32 orang. Metode yang digunakan dalam penelitian ini berupa Penelitian Tindakan Kelas (PTK) yang berlangsung selama dua siklus. Rancangan dari setiap siklusnya mencakup empat tahap yakni perencanaan tindakan, pelaksanaan tindakan, evaluasi, serta refleksi.

Pada tahap perencanaan tindakan didasarkan pada hasil observasi awal peneliti di kelas IX A melalui wawancara terhadap siswa. Hasil wawancara menunjukkan permasalahan pembelajaran di kelas yang diperlukan pemecahannya sebagai upaya meningkatkan prestasi belajar siswa dalam pembelajaran matematika ialah kurangnya aktivitas siswa dalam pembelajaran, pemahaman konsep, dan konsentrasi. Setelah memperoleh informasi mengenai permasalahan tersebut, selanjutnya dilakukan identifikasi faktor pemicu yang lain diantaranya: (1) pembelajaran kurang demokratis sebab cenderung satu arah; (2) kurangnya memanfaatkan alat peraga dalam pembelajaran; dan (3) masih kurang maksimalnya bimbingan pembelajaran dari guru pada kelompok siswa maupun individu. Hasil observasi terhadap prestasi belajar matematika masih rendah, peserta didik yang mencapai KKM masih kurang dari 50\%. Dari hasil observasi kemudian dilakukan perencanaan solusi untuk mengatasi masalah tersebut.

Selanjutnya, tahapan perencanaan dalam menyusun program tindakan pembelajaran dalam arti luas, berjalan semenjak ditelitinya silabus, standar isi, hingga penyusunan Rencana Pelaksanaan Pembelajaran (RPP) dan instrumen untuk mengumpulkan data. Instrumen penelitian 
ini berbentuk tes uraian guna mengumpulkan data prestasi belajar matematika siswa serta lembar observasi guna mengumpulkan data aktivitas siswa dan guru selama berlangsungnya pembelajaran.

Pada tahap pelaksanaan tindakan, pelaksanaan pembelajaran memanfaatkan model pembelajaran kooperatif tipe STAD dengan media software Pesona Edu untuk meningkatkan prestasi belajar matematika siswa dilakukan dalam dua siklus dimana tiap siklusnya terdapat tiga kali pertemuan. Sintaks model kooperatif tipe STAD dalam penelitian ini mengacu pada Slavin (Anifah et al., 2014) adalah mempunyai komponen presentasi kelas, pengembangan individu, kerja kelompok, serta evaluasi. Secara rinci tahapan kegiatan pembelajaran yang dilakukan yaitu: (1) memberitahukan kegiatan yang hendak dilakukan, inti materi ajar, dan kompetensi dasar; (2) LKS diberikan sesuai dengan materi ajar; (3) materi ajar disampaikan dengan simpel, sistematis, serta media pembelajarannya memanfaatkan software Pesona Edu yang bisa membantu pemahaman peserta didik; (4) membimbing dan mendorong peserta didik untuk menyampaikan idenya; (5) memberikan tugas secara individu ataupun kelompok dengan petunjuk yang jelas; (6) memberikan bimbingan untuk proses penyelesaian tugas tersebut; (7) merespon seluruh perilaku dan pendapat peserta didik; (8) membimbing peserta didik dalam merangkum materi ajar; dan (9) melakukan evaluasi untuk mengecek pemahaman peserta didik

Pada tahap evaluasi, dilakukan prosedur pengumpulan data penelitian, meliputi: (1) tes pada setiap akhir tindakan, dimana tujuannya untuk melihat meningkatnya pemahaman siswa atas materi yang dipelajarinya sesudah tindakan diberikan. Pemberian tes tersebut berbentuk soal uraian, sebab peneliti hendak mengetahui secara rinci proses jawaban siswa; dan (2) observasi, dimaksudkan guna mengamati aktivitas siswa selama dilakukannya penelitian, sebagai cara untuk melihat terdapatnya keselarasan antara pelaksanaan tindakan dengan perencanaan tindakan, serta untuk melihat seberapa jauh tindakan bisa menghasilkan perubahan seperti yang peneliti harapkan.

Data aspek kognitif peserta didik selanjutnya dilakukan analisis secara deskriptif yakni menentukan nilai KK (Ketuntasan Klasikal), KI (Ketuntasan Individual), dan rata-rata. Indikator keberhasilan tindakan yang dilakukan adalah nilai rata-rata mencapai sama dengan atau melebihi standar KKM (Kriteria Ketuntasan Minimum) dari SMP Negeri 7 Kota Tasikmalaya yaitu 70 serta ketuntasan klasikal sama dengan atau melebihi $80 \%$.

Data aktivitas belajar siswa dianalisis secara deskriptif. Penentuan keberhasilan pembelajaran yang selaras akan tujuan penelitian ini menggunakan hasil skor dalam persentase (\%) dengan tingkat keaktifan siswa dalam kriteria baik minimal 80\%. Keaktifan siswa ketika belajar diamati menggunakan indikator yang sudah ditetapkan, yakni: (1) mempresentasikan hasil kerja kelompok; (2) mengerjakan soal dan lembar kegiatan; (3) mengemukakan pendapat dalam kelompok; (4) berpartisipasi dalam diskusi kelompok; (5) mengajukan pertanyaan kepada guru; (6) merespon pertanyaan dan intruksi guru; (7) mencatat penjelasan guru; dan (8) mendengar dan memperhatikan presentasi guru (Khasanah, 2016). Kriteria keaktifan siswa dijabarkan pada Tabel 1.

Tabel 1. Kriteria keaktifan siswa selama pembelajaran

\begin{tabular}{cc}
\hline Persentase & Kriteria \\
\hline$<20 \%$ & Sangat Kurang \\
$20-39 \%$ & Kurang \\
$40-59 \%$ & Cukup \\
$60-79 \%$ & Baik \\
$\geq 80 \%$ & Sangat baik \\
\hline
\end{tabular}

Pada tahap refleksi, dilakukan tindakan apabila pada akhir siklus pertama menunjukkan sudah memenuhi indikator keberhasilan tindakan maka PTK dianggap sudah tuntas dan apabila belum terpenuhi maka tindakan dilanjutkan dengan menyusun kembali perencanaan siklus kedua dan seterusnya hingga terpenuhinya kriteria keberhasilan tindakan yang dilakukan. 


\section{HASIL DAN PEMBAHASAN \\ Hasil Penelitian}

Pelaksanaan penelitian tindakan sebanyak dua siklus dengan tiap siklus meliputi tiga kali tatap muka. Penjabaran kegiatan serta hasil penelitian, sebagai berikut:

\section{Siklus I}

Pemecahan permasalahan yang peneliti gunakan sebagai tindakan, yakni perbaikan pada proses belajar mengajar. Perbaikan pada siklus pertama adalah model pembelajaran dimana umumnya lebih berpusat pada guru (teacher centered) serta searah diperbaiki menjadi model pembelajaran kooperatif tipe STAD dengan memanfaatkan software Pesona Edu. Kegiatan menggunakan model pembelajaran ini berpusat pada siswa (student centered). Secara umum, pengaplikasian kombinasi pembelajaran ini dimulai dengan pertemuan klasikal guna memberi penjelasan mengenai tugas yang akan dikerjakan, informasi dasar, dan berbagai hal yang lainnya yang dirasa diperlukan. Sesudah pertemuan secara klasikal, selanjutnya ialah penerapan latihan terkontrol (peserta didik diberikan peluang untuk kerja dalam kelompok), dan kemudian pengaplikasian latihan mandiri (bekerja secara perorangan).

Pelaksanaan proses pembelajaran pada siklus I sebanyak tiga kali pertemuan dengan jangka waktu enam jam pelajaran. Tindakan pembelajarannya dilaksanakan dua kali pertemuan serta tes hasil belajarnya dilaksanakan satu kali pertemuan. Sementara pelaksanaan observasi keaktifan siswa dilakukan ketika berlangsungnya proses belajar mengajar. Pada akhir siklus I dilakukan tes guna mengetahui hasil belajar kognitif siswa menggunakan soal uraian agar lebih jelas dapat menggambarkan kemampuan dan pemahaman siswa terhadap konsep-konsep materi yang diberikan.

Materi yang diberikan pada siklus I yaitu statistika. Kelas dikelompokkan dalam enam kelompok, dimana tiap kelompoknya terdiri dari lima siswa. Pengelompokan siswa pada siklus I dilaksanakan dengan mempertimbangkan hasil ulangan I. Masing-masing kelompok memiliki kemampuan kognitif heterogen sehingga setiap kelompoknya meliputi siswa dengan kemampuan akademik bawah, sedang, dan atas.

Dari enam kelompok yang di dalamnya terdapat lima hingga enam siswa masih terlihat cenderung mementingkan penonjolan individu. Kondisi tersebut terlihat dari siswa dalam kelompok cenderung menyukai melakukan pengerjaan ke depan kelas sebelum membantu pemahaman teman satu kelompoknya. Upaya peneliti dalam mengatasi ini, berulang kali memberitahu supaya soal dalam LKS terlebih dahulu didiskusikan dengan kelompoknya, serta bagi siswa yang kurang paham supaya menanyakannya pada teman satu kelompoknya.

Peneliti pada setiap awal pembelajaran selalu memberi informasi kegiatan yang dilakukan, inti materi ajar, tujuan pembelajaran, dan membimbing siswa dengan tujuan guna menciptakan hubungan baik dengan siswa. Dari enam kelompok, terlihat satu kelompok yakni kelompok keenam cenderung kurang serius serta aktif selama berlangsungnya pembelajaran sehingga memerlukan perhatian lebih dari guru. Data hasil belajar kognitif penelitian siklus I secara terperinci disajikan pada Tabel 2.

Tabel 2. Rekapitulasi hasil belajar siklus I

\begin{tabular}{|c|c|c|c|c|c|c|c|}
\hline \multirow{3}{*}{$\begin{array}{l}\text { Jumlah } \\
\text { siswa }\end{array}$} & \multicolumn{3}{|c|}{ Hasil belajar kognitif } & \multicolumn{4}{|c|}{ Ketuntasan belajar klasikal } \\
\hline & \multirow{2}{*}{ Nilai tertinggi } & \multirow{2}{*}{ Nilai terendah } & \multirow{2}{*}{ Nilai rata-rata } & & & & \\
\hline & & & & Jml & $\%$ & $\mathrm{Jml}$ & $\%$ \\
\hline 32 orang & 82 & 42 & 62 & 8 & 25 & 24 & 75 \\
\hline
\end{tabular}

Berdasarkan Tabel 2 hasil pengolahan data penelitian pada akhir siklus I nampak bahwa dari 32 siswa di kelas IX A SMP Negeri 7 Kota Tasikmalaya diperoleh nilai rata-rata hasil belajar siklus I sebesar 62. Hasil ini menandakan bahwa KKM yang ditetapkan belum tercapai. Kekeliruan siswa dalam mengerjakan tes mayoritas disebabkan pemahaman konsep yang kurang, serta kekeliruan dalam membuat diagram/grafik dan menyusun data yang diminta sehingga memerlukan perbaikan pada siklus selanjutnya. 
Observasi keaktifan siswa pada siklus I menunjukkan hasil sebanyak $37,5 \%$ atau 12 orang siswa yang tergolong kategori keaktifan baik, sebanyak $46,9 \%$ atau 15 orang siswa tergolong kategori cukup, dan sebanyak $15,6 \%$ atau 5 orang siswa masih dalam kategori keaktifan kurang. Tingkat keaktifan siswa pada siklus I ditunjukkan pada Gambar 1.
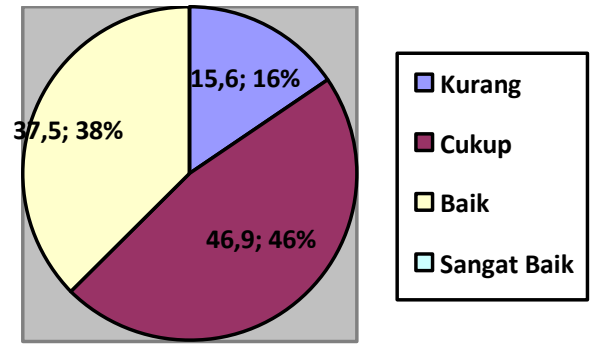

Gambar 1. Persentase keaktifan siswa siklus I

Berdasarkan pembelajaran siklus I diperoleh hasil belajar rata-rata nilai matematika, tingkat ketuntasan klasikal, dan tingkat keaktifan siswa belum memenuhi kriteria keberhasilan tindakan yang diharapkan sehingga tindakan dilanjutkan dengan siklus kedua untuk memperbaiki berbagai kekurangan saat pelaksanaan siklus I.

\section{Siklus II}

Materi pada siklus II adalah peluang, dimana pelaksanannya dalam tiga kali pertemuan dengan jangka waktu enam jam pelajaran. Pelaksanaan tindakan pembelajaran dilakukan sebanyak dua kali pertemuan serta tes hasil belajar dilakukan satu kali pertemuan. Perbaikan pada siklus II dengan mengacu pada observasi siklus I diantaranya: (1) siswa yang tergolong kurang diberikan motivasi untuk mewakili kelompoknya mempresentasikan hasil kerja kelompok; (2) guru memberikan bimbingan pada kelompok yang kesusahan dalam mencari pemecahan masalah; (3) pengaturan ulang pengelompokkan siswa dengan menyesuaikan hasil tes siklus I; dan (4) pengulangan tayangan media yang dianggap penting.

Pelaksanaan pembelajaran pada siklus II ini dilakukan perubahan kelompok, pengaturan ulang pengelompokan dengan menyesuaikan hasil belajar siklus I. Pelaksanaan diskusi pada siklus II berlangsung baik, siswa yang telah paham bersedia menjelaskan pada teman-teman kelompoknya yang belum paham, sementara untuk yang belum paham tidak malu mengajukan pertanyaan pada teman sekelompoknya. Sebagian siswa berani mengajukan pertanyaan pada guru jika terdapat soal yang belum bisa dikerjakannya. Sementara untuk mengerjakannya di papan tulis yakni dengan menunjuk wakil dari masing-masing kelompok. Penunjukan dilakukan oleh peneliti dimana tujuannya untuk memberi kesempatan pada siswa supaya lebih berani mengemukakan gagasannya. Peran guru pada siklus II cenderung lebih membimbing siswa yang memiliki perolehan hasil belajar kurang pada siklus I. Rekapituasi hasil belajar pada akhir siklus II disajikan pada Tabel 3.

Tabel 3. Rekapitulasi hasil belajar siklus II

\begin{tabular}{|c|c|c|c|c|c|c|c|}
\hline \multirow{3}{*}{$\begin{array}{l}\text { Jumlah } \\
\text { siswa }\end{array}$} & \multicolumn{3}{|c|}{ Hasil belajar kognitif } & \multicolumn{4}{|c|}{ Ketuntasan belajar klasikal } \\
\hline & Nilai tortinaai & Nilai torendah & Nilai & & & & ntas \\
\hline & Thial tertunger & ovial terenuán & Nilal rata-rata & $\mathrm{Jml}$ & $\%$ & $\mathrm{Jml}$ & $\%$ \\
\hline 32 orang & 91 & 63 & 78,22 & 28 & 87,5 & 4 & 12,5 \\
\hline
\end{tabular}

Berdasarkan data pada Tabel 3, menunjukkan bahwa rata-rata prestasi belajar siswa mengalami peningkatan dari 16,22 menjadi 78,22 dengan ketuntasan $87,5 \%$ atau naik sebesar $62,5 \%$ dari siklus sebelumnya. Apabila dilakukan perbandingan dengan hasil siklus I naik dengan cukup memuaskan, perolehan nilai paling tinggi dari siklus I yakni 82 menjadi 91 pada siklus II, serta untuk nilai paling rendah dari 42 menjadi 63. Tingkat keaktifan siswa juga pada siklus II mengalami kenaikan dapat terlihat pada Gambar 2. 


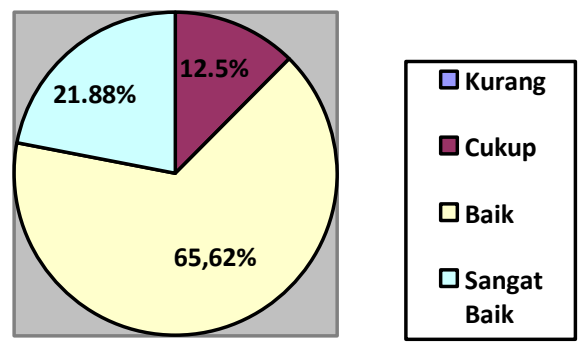

Gambar 2. Persentase keaktifan siswa siklus II

Berdasarkan Gambar 2 pada siklus II terjadi kenaikan keaktifan siswa selama pelaksanaan pembelajaran. Untuk siklus II siswa yang termasuk kategori keaktifan sangat baik sebanyak 21,9\% atau 7 orang siswa, sebanyak $65.62 \%$ atau 21 orang siswa dalam kategori keaktifan baik, dan sebanyak $12,5 \%$ atau 4 orang siswa dalam kategori cukup. Berdasarkan hasil tersebut sudah melampaui kriteria minimal keberhasilan tindakan yaitu total ada $87,52 \%$ siswa yang sudah minimal memiliki keaktifan baik. Berdasarkan hasil tersebut berarti tindakan dikatakan berhasil dan tidak diperlukan siklus selanjutnya. Rekapitulasi peningkatan hasil belajar setiap siklus secara lengkap disajikan pada Tabel 4.

Tabel 4. Perbandingan hasil belajar siklus I dan II

\begin{tabular}{|c|c|c|c|c|c|c|c|}
\hline \multirow{3}{*}{$\begin{array}{l}\text { Jumlah } \\
\text { siswa }\end{array}$} & \multicolumn{3}{|c|}{ Hasil belajar kognitif } & \multicolumn{4}{|c|}{ Ketuntasan belajar klasikal } \\
\hline & \multirow{2}{*}{ Nilai tertinggi } & \multirow{2}{*}{ Nilai terendah } & \multirow{2}{*}{ Nilai rata-rata } & \multicolumn{2}{|c|}{ Tuntas } & \multicolumn{2}{|c|}{ Belum tuntas } \\
\hline & & & & $\mathrm{Jml}$ & $\%$ & $\mathrm{Jml}$ & $\%$ \\
\hline 32 orang & 82 & 42 & 62 & 8 & 25 & 24 & 75 \\
\hline 32 orang & 91 & 63 & 78,22 & 28 & 87,5 & 4 & 12,5 \\
\hline Peningkatan & 9 & 21 & 16.22 & 20 & 62.5 & & \\
\hline
\end{tabular}

Berdasarkan Tabel 4, diketahui bahwa terdapat peningkatan yang signifikan hasil belajar matematika antara siklus I dan siklus II. Sehingga, pengaplikasian model pembelajaran kooperatif STAD menggunakan media software Pesona Edu bisa menjadikan hasil belajar meningkat, serta aktifitas belajar matematika siswa kelas IX A SMP Negeri 7 Tasikmalaya Tahun pelajaran 2015/2016 juga meningkat. Perbandingan tingkat keaktifan siswa selama tindakan disajikan secara lebih jelas pada Gambar 3.

Diagram Perbandingan Keaktifan Siswa Pada Siklus I dan II

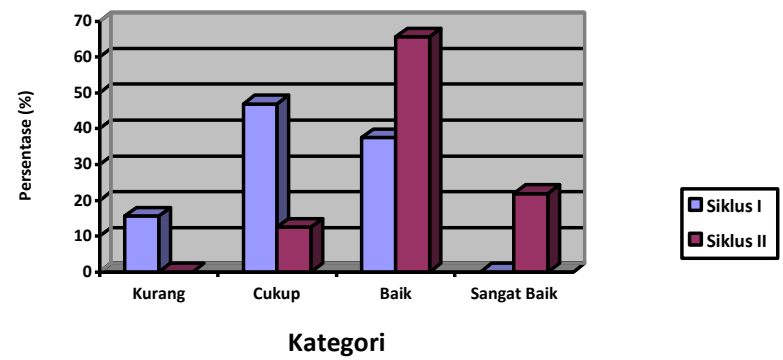

Gambar 3. Perbandingan keaktifan siswa pada siklus I dan II

\section{Pembahasan}

Hasil penelitian ini selaras dengan penelitian Mariani (2016); Sutriyono \& Putri (2018) yang menyatakan bahwa dalam pelaksanaan pembelajaran menggunakaan model pembelajaran kooperatif tipe STAD bisa terjadi proses saling membantu antar anggota kelompok untuk memecahkan masalah matematika dan memahami konsep-konsep matematika dengan kelompoknya. Pada proses pelaksanaan model kooperatif STAD juga berakibat terhadap peningkatan keaktifan siswa dalam pembelajaran, ditadai dengan siswa berani mengajukan pendapat, dapat bertangung jawab dan bisa saling membantu teman satu kelompok ataupun beda 
kelompok. Keunggulan-keunggulan inilah yang berakibat terhadap peningkatan hasil belajar matematika siswa.

Faktor lain pada penelitian ini yang menjadikan peningkatan aktivitas dan hasil belajar matematika ialah media software Pesona Edu yang dimanfaatkan sebagai sumber belajar siswa pada saat proses menemukan pemecahan permasalahan. Uraian hasil ini selaras dengan hasil penelitian Sastrawan et al. (2014) dan Suyahya (2014) menyatakan bahwa media Pesona Edu bisa menjadikan aktivitas dan hasil belajar siswa meningkat. Media Pesona Edu membantu siswa dalam membangun konsep pengetahuan sendiri sehingga proses internalisasi pengetahuan baru yang diperoleh siswa menjadi lebih optimal.

Uraian hasil penelitian ini selaras dengan teori Bruner (Suwarsono, 2002) tentang proses internalisasi pengetahuan dengan sungguh-sungguh akan terjadi (dimana artinya terjadinya proses pembelajaran secara maksimal) apabila pengetahuan tersebut dipelajari dalam beberapa tahapan meliputi: (1) tahap enaktif yakni secara aktif mempelajari pengetahuan dengan memanfaatkan situasi yang nyata atau benda-benda; (2) tahap ikonik yakni pengetahuan diwujudkan (direpresentasikan) berbentuk visual imagery (bayangan visual), diagram atau gambar yang menunjukkan situasi atau kegiatan konkret dalam tahap enaktif; dan (3) tahap simbolik yakni pengetahuan tersebut direpresentasikan berbentuk berbagai simbol abstrak, baik lambang-lambang matematika, simbol verbal (seperti kalimat-kalimat, kata-kata, maupun huruf-huruf), ataupun berbagai lambang abstrak yang lain.

Proses belajar akan berlangsung dengan maksimal apabila pembelajarannya dimulai dengan tahap enaktif, serta selanjutnya apabila tahap belajar pertama ini dianggap sudah cukup, siswa berlanjut menuju tahap belajar kedua, yakni memanfaatkan modus representasi ikonik. Berikutnya, aktivitas belajar tersebut berlanjut ke tahap ketiga, yakni tahap belajar memanfaatkan modus representasi simbolik. Untuk siswa SMP kelas IX yang tengah mempelajari materi statistika dan peluang, pada tahap enaktif siswa diberikan contoh mengenai aktivitas dalam keseharian yang berkaitan dengan statistika dan peluang.

Dalam tayangan software Pesona Edu siswa dapat melihat betapa banyak kegiatan yang ditayangkan sebenarnya biasa dialaminya dan bisa dinyatakan dalam bentuk statistika. Kemudian, siswa pada tahap ikonik bisa diberi penjelasan mengenai kegiatan-kegiatan yang mereka alami seperti menyebutkan hobi, ukuran sepatu, tinggi badan, berat badan mereka dapat dibuat dalam bentuk tabel atau diagram (batang, garis, lingkaran dan piktograf) yang kemudian pada tahap simbolik siswa diberikan pembimbingan untuk bisa memberi definisi secara simbolik mengenai statistika baik dengan lambang-lambang matematika ataupun lambang-lambang verbal. Proses inilah yang bisa menjadikan hasil belajar dan aktivitas siswa meningkat karena pembelajaran menjadi lebih menantang dan menyenangkan serta meningkatkan rasa ingin tahu siswa karena konsep matematika yang abstrak bisa menjadi lebih konkret sesuai dengan yang ditemukan dalam keseharian siswa.

\section{KESIMPULAN}

Berdasarkan hasil analisis data penelitian ini diperoleh kesimpulan bahwa penerapan model pembelajaran kooperatif tipe STAD dengan media software Pesona Edu dapat meningkatkan aktivitas dan hasil belajar matematika siswa kelas IX A SMP Negeri 7 Tasikmalaya Tahun Pelajaran 2015/2016 pada materi statistika dan peluang.

\section{REKOMENDASI}

Hasil penelitian ini masih memerlukan penelitian lanjutan yaitu penerapan model kooperatif tipe STAD dengan memanfaatkan media sottware Pesona Edu pada pokok bahasan yang lain dan atau pada tingkat kelas yang lebih rendah, sehingga dapat mengembangkan penelitian ini lebih mendalam. 


\section{UCAPAN TERIMAKASIH}

Peneliti mengucapkan terima kasih pada kepala sekolah, guru-guru dan seluruh siswa yang membantu terlaksananya penelitian ini sehingga bisa berjalan dengan lancar dan baik.

\section{DAFTAR PUSTAKA}

Anifah, N., Suryani, N., \& Haryati, S. (2014). Pengaruh model pembelajaran student teams achievement divisions (stad) dan konvensional terhadap prestasi belajar siswa ditinjau dari minat belajar pada mata pelajaran ips kelas vii mts negeri di kabupaten kudus. Jurnal Teknologi Pendidikan dan Pengajaran, 2(2), 185-198.

Aprilia, H., \& Putri, L. I. (2020). Penggunaan media diorama: solusi pembelajaran matematika materi skala terhadap kemampuan berpikir tingkat tinggi jenjang dasar. Teorema: Teori dan Riset Matematika, 5(2), 143-155. Doi: http://dx.doi.org/10.25157/teorema.v5i2.3402.

Jamuri., Kosim., \& Doyan, A. (2015). Pengaruh model pembelajaran kooperatif stad berbasis multimedia interaktif terhadap penguasaan konsep siswa pada materi termodinamika. Jurnal Penelitian Pendidikan IPA (JPPIPA), 1(1),123-134. Doi: 10.29303/jppipa.v1i1.11

Khasanah, F. (2016). Meningkatkan keaktifan belajar siswa melalui model pembelajaran kooperatif tipe stad (students teams achievement division). LIKHITAPRAJNA, 18(2), 48-57. Retrieved from: http://likhitapradnya.wisnuwardhana.ac.id/index.php/likhitapradnya/article/view/58.

Mariani. (2016). Peningkatan aktivitas dan hasil belajar siswa kelas vii 1 smpn 7 kubung dengan menggunakan model pembelajaran kooperatif tipe stad. Jurnal Penelitian Guru Indonesia, 1(1), 57-62. Doi: https://doi.org/10.29210/0249jpgi0005

Munaji \& Setiawahyu, M. I. (2020). Profil kemampuan matematika siswa smp di kota cirebon berdasarkan standar timss. Teorema: Teori dan Riset Matematika, 5(2), 249-262. Doi: http://dx.doi.org/10.25157/teorema.v5i2.3732.

Novitasari, D. (2016). Pengaruh penggunaan multimedia interaktif terhadap kemampuan pemahaman konsep matematika siswa. FIBONACCl: Jurnal Pendidikan Matematika dan Matematika, 2(2), 8-18. Retrieved from: https://jurnal.umj.ac.id/index.php/fbc/article/view/1650/1402

Nurhayati, Y., Zakiah, N. E., \& Amam, A. (2020). Integrasi contextual teaching learning (ctl) dengan geogebra: dapatkah meningkatkan kemampuan koneksi matematis siswa?. Teorema: Teori dan Riset Matematika, 5(1), 27-34. Doi: http://dx.doi.org/10.25157/teorema.v5i1.3349.

Putri, K. C., \& Sutriyono (2018). Pengaruh metode pembelajaran stad terhadap hasil belajar matematika pada siswa kelas viii. Jurnal Mosharafa, 7(2), 295-306. Doi: https://doi.org/10.31980/mosharafa.v7i2.358.

Rakhmawati, E. (2012). Pengaruh metode bermain kreatif terhadap prestasi belajar matematika anak sekolah dasar. Majalah IImiah Pendidikan Dasar, 2(2), 51-57. Doi: https://doi.org/10.26877/malihpeddas.v2i2.502

Sastrawan, W., Sedanayasa, G., \& Suwatra, I. I. W. (2014). Pengaruh model pembelajaran kooperatif tipe numbered heads together (nht) dengan bantuan media software pembelajaran terhadap hasil belajar ipa siswa kelas v sd gugus iii desa bengkel kecamatan 
busungbiu. Jurnal Mimbar PGSD Universitas Pendidikan Ganesha, 2(1). Doi: http://dx.doi.org/10.23887/jjpgsd.v2i1.2308

Shodiqin, A., \& Fakhrudin. (2011). Pembelajaran matematika dengan bantuan software mathematica untuk meningkatkan hasil belajar matematik mahasiswa calon guru matematika: studi eksperimen pada mahasiswa calon guru matematika di ikip pgri semarang. Jurnal Matematika dan Pendidikan Matematika UPGRIS Semarang, 2(1), 1-22.

Sobel, M., \& Maletsky, M. E. (2001). Mengajar matematika. Jakarta: Erlangga.

Suhito. (2000). Interaksi belajar mengajar. Jakarta: Depdiknas.

Suwarsono. (2002). Teori-teori perkembangan kognitif dan proses pembelajaran yang relevan untuk pembelajaran matematika. Jakarta: Depdiknas.

Suyahya, I. (2014). Efektifitas pelaksanaan strategi pembelajaran flipped classrom dengan memanfaatkan media pembelajaran software pesona edu dalam meningkatkan prestasi belajar siswa di smp jakarta. Prosiding Seminar Nasional Hasil-Hasil Penelitian (SNHP-IV) Universitas PGRI Semarang,186-192. 